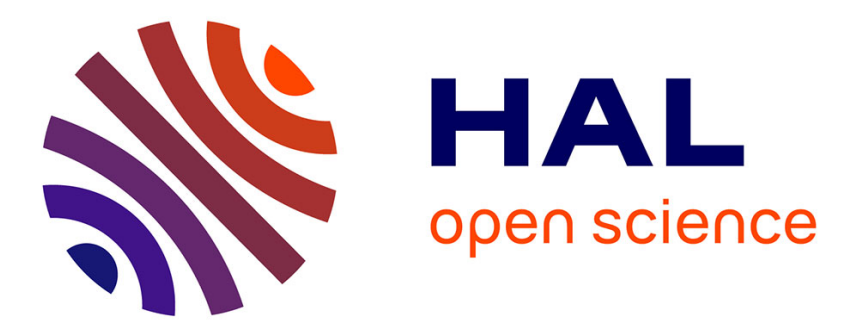

\title{
Synthesis and photovoltaic performances in solution-processed BHJs of oligothiophene-substituted organocobalt complexes [([small eta]4-C4(nT)4) $\mathrm{Co}([$ small eta $] 5-\mathrm{C} 5 \mathrm{H} 5)]$
}

Guillaume H. V. Bertrand, Ludovic Tortech, Vincent Gandon, Corinne Aubert, Denis Fichou

\section{To cite this version:}

Guillaume H. V. Bertrand, Ludovic Tortech, Vincent Gandon, Corinne Aubert, Denis Fichou. Synthesis and photovoltaic performances in solution-processed BHJs of oligothiophene-substituted organocobalt complexes [([small eta $] 4-\mathrm{C} 4(\mathrm{nT}) 4) \mathrm{Co}([$ small eta $] 5-\mathrm{C} 5 \mathrm{H} 5)]$. Chemical Communications, 2014, 50 (63), pp.8663-8666. 10.1039/c4cc03530e . hal-01156581

\section{HAL Id: hal-01156581 \\ https://hal.science/hal-01156581}

Submitted on 17 Nov 2015

HAL is a multi-disciplinary open access archive for the deposit and dissemination of scientific research documents, whether they are published or not. The documents may come from teaching and research institutions in France or abroad, or from public or private research centers.
L'archive ouverte pluridisciplinaire HAL, est destinée au dépôt et à la diffusion de documents scientifiques de niveau recherche, publiés ou non, émanant des établissements d'enseignement et de recherche français ou étrangers, des laboratoires publics ou privés. 
Cite this: Chem. Commun., 2014, 50,8663

Received 10th May 2014, Accepted 30th May 2014

DOI: $10.1039 / c 4 c c 03530 e$

www.rsc.org/chemcomm

\section{Synthesis and photovoltaic performances in solution-processed BHJs of oligothiophene- substituted organocobalt complexes $\left.\left[\left(\eta^{4}-\mathrm{C}_{4}(n \mathrm{~T})\right)_{4}\right) \mathrm{Co}\left(\eta^{5}-\mathrm{C}_{5} \mathrm{H}_{5}\right)\right] \dagger$}

\author{
Guillaume H. V. Bertrand, ${ }^{\mathrm{ab}}$ Ludovic Tortech, ${ }^{\star a c}$ Vincent Gandon, ${ }^{\mathrm{d}}$ Corinne Aubert ${ }^{\mathrm{ab}}$ \\ and Denis Fichou*ab
}

\begin{abstract}
We describe an efficient synthetic route toward novel organocobalt complexes $\left[\left(\eta^{4}-\mathrm{C}_{4}(n \mathrm{~T})_{4}\right) \mathrm{Co}\left(\eta^{5}-\mathrm{C}_{5} \mathrm{H}_{5}\right)\right]$ with $n=1,2,3$ thiophene rings. Solution-processed bulk heterojunctions solar cells based on $\mathrm{CpCoCb}(3 \mathrm{~T})_{4}: \mathrm{PCBM}$ blends achieve power conversion efficiencies of up to $2.1 \%$.
\end{abstract}

Organic solar cells (OSC) based on polymer bulk heterojunctions (BHJ) proved to be a versatile strategy to engineer efficient and low-cost photovoltaic devices. ${ }^{1}$ Power conversion efficiencies (PCEs) in the range 6-8\% have been attained using single BHJ devices using solution-processed polymer/fullerene blends. A tandem cell based on a low band gap polymer has been recently reported to exhibit a certified PCE as high as $10.6 \%{ }^{1 g}$

Meanwhile, BHJs made of small organic molecules emerged as a new approach with the advantages over polymers of a better control of the molecular design, a higher purity, an improved structural organization and an absence of batch-to-batch variations. $^{2}$ A wealth of small organic dyes such as squaraines, ${ }^{3}$ porphyrins, ${ }^{4}$ diketopyrrolopyrroles, ${ }^{5}$ or oligothiophenes, ${ }^{6,7}$ to name a few, have been experimented in solution-processed BHJs. Note that these small organic molecules are acting as donor (p-type) constituents of the BHJ, often in combination with a fullerene derivative as the acceptor (n-type) although nonfullerene acceptors such as perylenes were also thoroughly investigated. $^{8}$ A PCE of $6.7 \%$ has been recorded under AM 1.5 global irradiation $\left(100 \mathrm{~mW} \mathrm{~cm}^{-2}\right)$ with a $\mathrm{BHJ}$ device made from $\operatorname{DTS}\left(\mathrm{PTTh}_{2}\right)_{2}$, a thiadiazole derivative, blended with $\mathrm{PC}_{70} \mathrm{BM}^{2 b}$ This high efficiency originates essentially from an intense optical

\footnotetext{
${ }^{a}$ Sorbonne Universités, UPMC Univ Paris 06, UMR 8232, Institut Parisien de Chimie Moléculaire, F-75005, Paris, France. E-mail: denis.fichou@upmc.fr, ludovic.tortech@upmc.fr; Fax: +33 144275572; Tel: +33 144275080

${ }^{b}$ CNRS, UMR 8232, Institut Parisien de Chimie Moléculaire, F-75005, Paris, France

${ }^{c}$ CEA Saclay, IRAMIS, NIMBE, LICSEN, F-91191 Gif-sur-Yvette, France

${ }^{d}$ Universite Paris-Sud, ICMMO (UMR CNRS 8182), LabEx CHARM ${ }_{3} A T$, F-91405 Orsay, France

$\dagger$ Electronic supplementary information (ESI) available: Experimental details on the synthesis and electronic properties the of $\operatorname{CpCoCb}(n \mathrm{~T})_{4}$ complexes, fabrication and testing of the photovoltaic devices. See DOI: 10.1039/c4cc03530e
}

absorption over the entire visible spectrum and an appropriate morphology leading to a high hole mobility $\left(0.12 \mathrm{~cm}^{2} \mathrm{~V}^{-1} \mathrm{~s}^{-1}\right)$. Very recently, by using the same thiadiazole dye, the PCE of a BHJ solar cell in an inverted structure reached values as high as $7.88 \%,{ }^{9}$ while record PCEs of over $8.0 \%$ were attained using a benzodithiophene derivative. ${ }^{6}$ These encouraging results pave the way towards small molecule-based OSCs with PCEs exceeding $10 \%$.

Among the plethora of small organic molecules currently investigated as active materials for OSCs, organometallic complexes represent an attractive class of materials. In particular organometallic dyes based on noble metals (such as Ru, Rh or Ir) are extensively utilized as photosensitizers solar cells of various types..$^{10}$ Besides, organometallic complexes based on 3d-transition metals (such as $\mathrm{Co}, \mathrm{Ni}, \mathrm{Cu}, \mathrm{Zn}$, etc.) are also studied for solar energy conversion, in particular the large family of metallophthalocyanines. ${ }^{11}$ When attached to organic ligands 3d-transition metals induce metal-ligand charge transfer (MLCT) transitions spanning over the visible and near infrared spectra. ${ }^{10 b}$ Finally, note that $3 \mathrm{~d}$ metals also possess intra-3d transitions absorbing strongly in the visible region that have been used to sensitize wide bandgap oxides such as $\mathrm{ZnO}, \mathrm{TiO}_{2}$ or $\mathrm{SrTiO}_{3}$, in view of solar energy conversion. ${ }^{12}$

We present here the synthesis and photovoltaic behaviour of novel oligothiophene-substituted organocobalt complexes with general formula $\left[\left(\eta^{4}-\mathrm{C}_{4} \mathrm{R}_{4}\right) \mathrm{Co}\left(\eta^{5}-\mathrm{C}_{5} \mathrm{H}_{5}\right)\right]$. The central $\mathrm{Co}(\mathrm{I})$ atom is linked to a cyclopentadienyl $\left(\eta^{5}-\mathrm{C}_{5} \mathrm{H}_{5}\right.$, noted $\left.\mathrm{Cp}\right)$ and a cyclobutadienyl $\left(\eta^{4}-\mathrm{C}_{4} \mathrm{R}_{4}\right.$, noted $\left.\mathrm{Cb}\right)$ ligands. Both planar $\mathrm{Cp}$ and $\mathrm{Cb}$ ligands are located at the apex of each other to form a 3D sandwich molecule. The $\mathrm{Cb}$ rings are substituted by four peripheral oligothiophene units $n \mathrm{~T}$ of various lengths $(n=1,2,3)$. The introduction of $\pi$-conjugated oligothiophene substituents on the $\mathrm{Cb}$ ring is expected to contribute to the MLCT transitions and to improve the charge transport in the $\mathrm{BHJ} .{ }^{13}$ Finally, we note that $\mathrm{CpCoCb}$ complexes substituted by appropriate groups on both the $\mathrm{Cp}$ and $\mathrm{Cb}$ rings have been extensively reported as altitudinal molecular rotors ${ }^{14}$ supramolecular cages,${ }^{15}$ or catalysts. ${ }^{16}$

The organic solar cells under study here are based on BHJs prepared by mixing the $\operatorname{CpCoCb}(n \mathrm{~T})_{4}$ complexes together with 


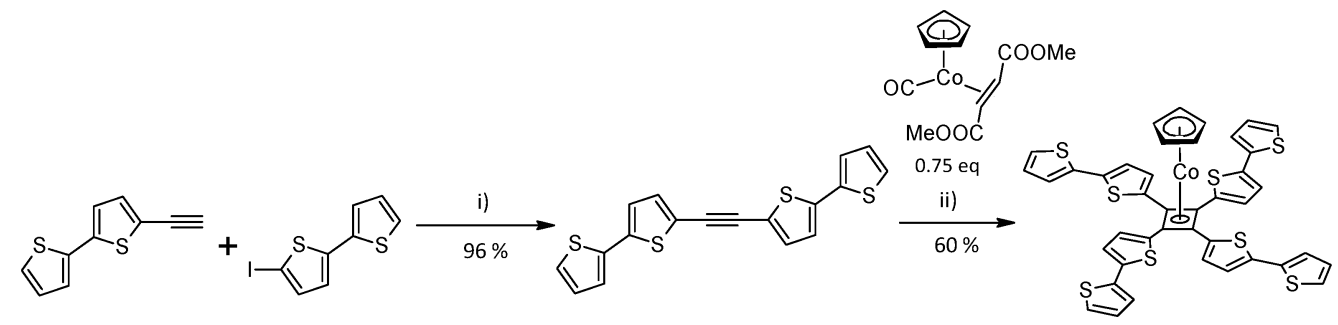<smiles>Brc1ccc(C#Cc2ccc(Br)s2)s1</smiles><smiles>COC(=O)CC(C)OC(C)=O</smiles>
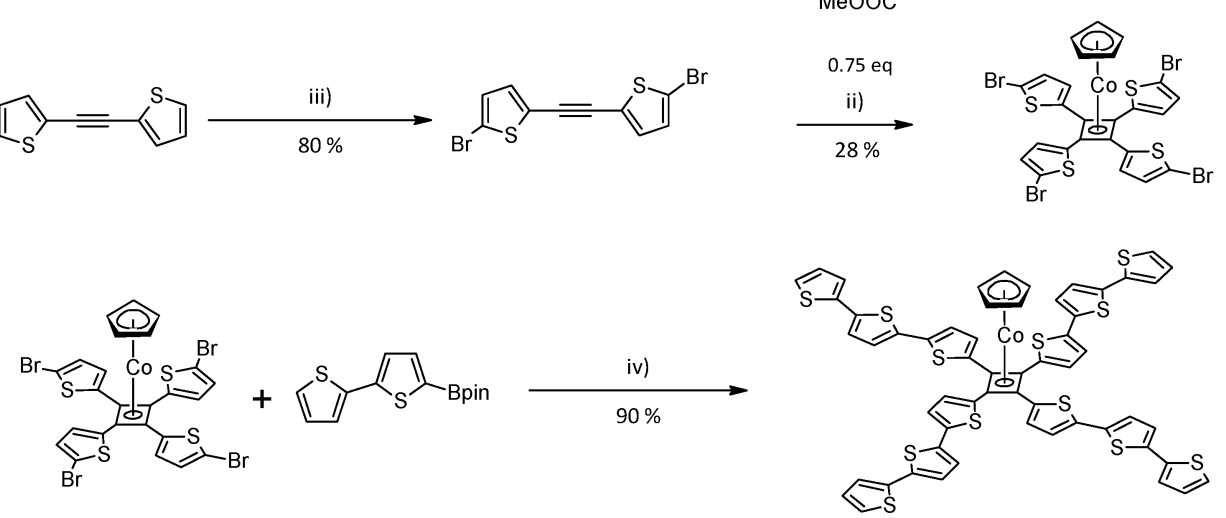

Scheme 1 Synthetic pathways to $\mathrm{CpCoCb}(n T)_{4}$ with $n=2$, 3. (i) $10 \mathrm{~mol} \% \mathrm{PdCl}_{2}\left(\mathrm{PPh}_{3}\right)_{2}, 10 \mathrm{~mol} \% \mathrm{Cul} \mathrm{NEt}$, RT, 24 h. (ii) $14 / 1 \mathrm{THF} / \mathrm{EtOH}$, microwave $150{ }^{\circ} \mathrm{C}, 30 \mathrm{~min}\left(P=80\right.$ W). (iii) 2.2 eq. BuLi, $\mathrm{THF},-40{ }^{\circ} \mathrm{C}, 30 \mathrm{~min}, \mathrm{Br}_{2}, \mathrm{RT}, 2 \mathrm{~h}$. (iv) 20 mol\% $\mathrm{PdCl}_{2}(\mathrm{dppf}), 16$ eq. $\mathrm{K}_{2} \mathrm{CO}_{3}, \mathrm{THF} / \mathrm{H}_{2} \mathrm{O}, \mathrm{reflux} 5 \mathrm{days}$.

[6,6]-phenyl-C60-butyric acid methyl ester (PCBM) as the acceptor material. The $\operatorname{CpCoCb}(n \mathrm{~T})_{4}$ complexes are soluble in usual organic solvents and can be easily processed via spin-coating. The device architecture was set to be $\left\{\right.$ glass/ITO/PEDOT:PSS/CpCoCb $(n \mathrm{~T})_{4}$ : PCBM/LiF/Al $\}$. PCEs of up to $1.87 \%$ under $75 \mathrm{~mW} \mathrm{~cm}^{-2}$ and $2.12 \%$ under $22 \mathrm{~mW} \mathrm{~cm}{ }^{-2}$ were recorded with $\mathrm{CpCoCb}(3 \mathrm{~T})_{4}$.

The three $\operatorname{CpCoCb}(n \mathrm{~T})_{4}$ complexes are conveniently synthesized according to an original strategy (Scheme 1). The synthesis of the shorter analog $\operatorname{CpCoCb}(1 \mathrm{~T})_{4}$ has already been described elsewhere, ${ }^{17}$ while $2 \mathrm{~T}$ and $3 \mathrm{~T}$ are novel compounds. The key step is the use of $\mathrm{CpCo}(\mathrm{CO})(\mathrm{DMFU})^{18}$ (with DMFU = dimethylfumarate) engaged in a [2+2] cycloaddition under microwave conditions developed in our laboratory. ${ }^{19}$ Precursors for $\operatorname{CpCoCb}(1 \mathrm{~T})_{4}$ and $\mathrm{CpCoCb}(2 \mathrm{~T})_{4}$ were synthesized using a Sonogashira type coupling. A first attempt to synthesize $\mathrm{CpCoCb}(3 \mathrm{~T})_{4}$ using the same approach was carried out but the bis(3T)-acetylene precursor proved to be very difficult to be isolated due to an ultra-low solubility $\left(<5 \mathrm{mg} \mathrm{L}^{-1}\right.$ in DCM). Therefore we investigated a second route based on a Suzuki coupling following the [2+2] cycloaddition, leading successfully to the target $\mathrm{CpCoCb}(3 \mathrm{~T})_{4}$ product. Surprisingly this complex was highly soluble in organic solvents $\left(\sim 20 \mathrm{mg} \mathrm{mL}{ }^{-1}\right.$ in $\mathrm{CH}_{2} \mathrm{Cl}_{2}$ and $35 \mathrm{mg} \mathrm{mL}^{-1}$ in 1,2-dichlorobenzene) in spite of the four $3 \mathrm{~T}$ units per molecule. The absorption spectra of the three $\operatorname{CpCoCb}(n \mathrm{~T})_{4}$ compounds (Fig. 1) exhibit a broad band with a bathochromic shift of $\lambda_{\max }$ from 1T $(254 \mathrm{~nm})$ to $2 \mathrm{~T}(354 \mathrm{~nm})$ and to $3 \mathrm{~T}(399 \mathrm{~nm})$. One can note that the molar extinction coefficient of $\mathrm{CpCoCb}(3 \mathrm{~T})_{4}$ reached values as high as $10^{4}-10^{5} \mathrm{~L} \mathrm{~mol}^{-1} \mathrm{~cm}^{-1}$ over the $300-600 \mathrm{~nm}$ range. Cyclic voltammetry experiments were performed on the three

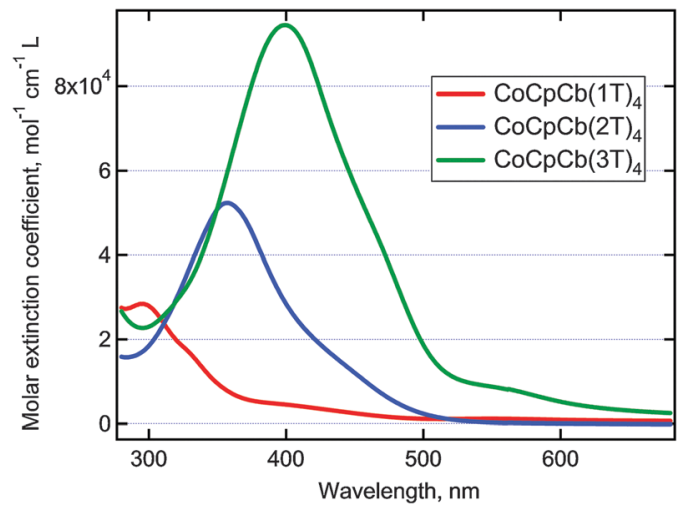

Fig. 1 Absorption spectra of the three $\mathrm{CpCoCb}(n \mathrm{~T}))_{4}$ complexes $(n=1,2,3)$ in dichloromethane.

$\operatorname{CpCoCb}(n \mathrm{~T})_{4}$ derivatives in order to complete their electronic structures (Fig. S1, ESI $\dagger$ ). As expected optical absorption $\left(\lambda_{\max }\right.$ and $\left.\varepsilon\right)$ and the oxidation potential $E_{1 / 2}^{\mathrm{ox}}$ scale the $n \mathrm{~T}$ chain length from $n=1$ to 3 . The energetic parameters deduced from optical and electrochemical data allow us to determine the HOMO levels using formula $(1)^{20}$ (Table S1, ESI $\dagger$ ):

$$
E_{\mathrm{HOMO}}=-(1.4 \pm 0.1) \times q\left(E_{\mathrm{ox}}-E_{\mathrm{ref}}\right)-(4.6 \pm 0.08) \mathrm{eV}
$$

The energetic data of the $\mathrm{CpCoCb}(3 \mathrm{~T})_{4}$ complex are then associated with the HOMO-LUMO levels of PCBM and the 
a)

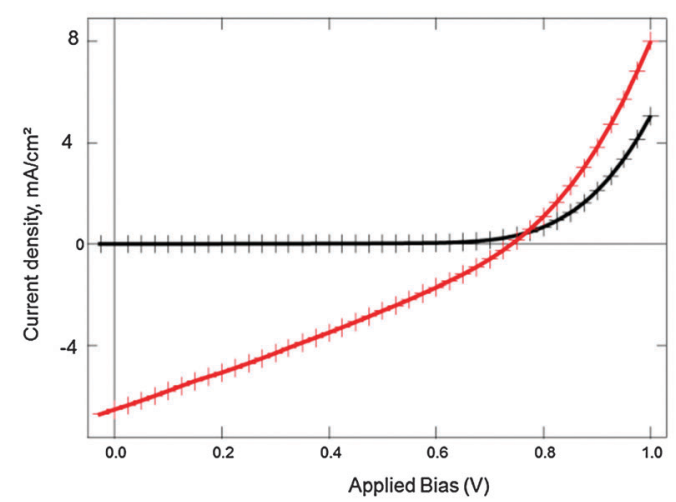

b)

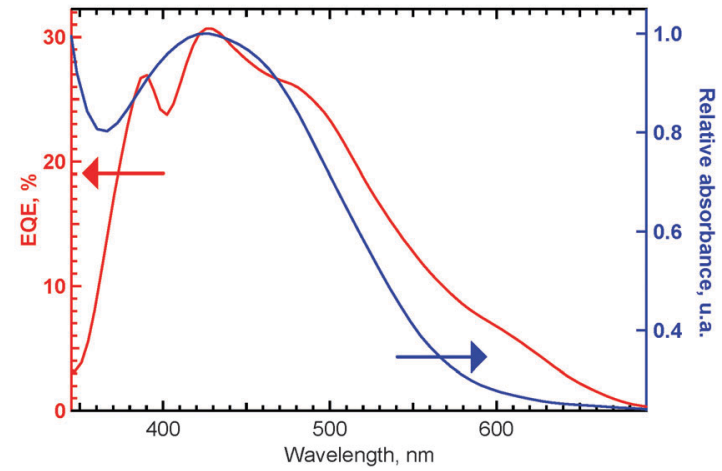

Fig. 2 (a) I/V response of an OSC based on a $\mathrm{CpCoCb}(3 \mathrm{~T})_{4}: \mathrm{PCBM} \mathrm{BHJ}$ in the dark (black) and under white light irradiation (AM 1.5G, $75 \mathrm{~mW} \mathrm{~cm}^{-2}$, red). (b) $E Q E$ (red) and absorption (blue) spectra of a $\mathrm{BHJ}$ device based on a $\mathrm{CpCoCb}(3 \mathrm{~T})_{4}: \mathrm{PCBM}$ blend.

Fermi levels of the ITO and Al electrodes used in the devices. The energetic diagram of a $\mathrm{BHJ}$ solar cell based on $\mathrm{CpCoCb}(3 \mathrm{~T})_{4}$ as the donor or and PCBM as the acceptor (Fig. S2, ESI $\dagger$ ) shows a typical staircase profile favourable for an efficient PV effect under visible light irradiation.

The $I / V$ characteristics of OSCs based on $\operatorname{CpCoCb}(n \mathrm{~T})_{4}$ in the dark and under white light illumination (AM $1.5 \mathrm{G}, 75 \mathrm{~mW} \mathrm{~cm}^{-2}$ ) are presented in Fig. 2a. In the dark the $I / V$ curve reveals excellent diode behaviour over the $-2.0 \mathrm{~V} /+2.0 \mathrm{~V}$ range (Fig. S4, ESI $\dagger$ ). Increasing the length of the four $n \mathrm{~T}$ units $(n=1,2,3)$ results in a considerable increase in the PCE up to $1.9 \%$ for $\operatorname{CpCoCb}(3 \mathrm{~T})_{4}$ (Table 1). When exposed to lower incident powers, the PCE increases up to $2.1 \%$ under $22 \mathrm{~mW} \mathrm{~cm}^{-2}$ (Fig. S5, ESI $\dagger$ ). Similarly, in open air $V_{\mathrm{oc}}$ is higher for the $3 \mathrm{~T}$ derivative $(608 \mathrm{mV})$ as compared to the shorter $1 \mathrm{~T}$ $(102 \mathrm{mV})$ and $2 \mathrm{~T}(331 \mathrm{mV})$ derivatives. The current density is also improved with longer $n \mathrm{~T}$ units, up to $J_{\mathrm{sc}}=6.2 \mathrm{~mA} \mathrm{~cm} \mathrm{~cm}^{-2}$ for

Table 1 PV characteristics under AM $1.5 \mathrm{G}\left(75 \mathrm{~mW} \mathrm{~cm}{ }^{-2}\right)$ of the $\mathrm{CpCoCb}(n \mathrm{~T}){ }_{4}$ complexes

\begin{tabular}{lllll}
\hline $\operatorname{CpCoCb}(n \mathrm{~T})_{4}$ complex & $J_{\mathrm{SC}}\left(\mathrm{mA} \mathrm{cm}^{-2}\right)$ & $V_{\mathrm{OC}}(\mathrm{mV})$ & $\mathrm{FF}(\%)$ & PCE $(\%)$ \\
\hline$n=1^{a}$ & 0.015 & 102 & 27 & 0.001 \\
$n=2^{a}$ & 3.15 & 331 & 28 & 0.05 \\
$n=3$ & $1.4^{a}$ & $608^{a}$ & $30^{a}$ & $0.35^{a}$ \\
& $6.4^{b}$ & $732^{b}$ & $30^{b}$ & $1.87^{b}$ \\
& $2.2^{c}$ & $664^{c}$ & $32^{c}$ & $2.12^{c}$
\end{tabular}

${ }^{a}$ In open air. ${ }^{b}$ Under $\mathrm{N}_{2} \cdot{ }^{c}$ Under $\mathrm{N}_{2}$ after annealing, under $22 \mathrm{~mW} \mathrm{~cm}{ }^{-2}$.
$\mathrm{CpCoCb}(3 \mathrm{~T})_{4}$ under $\mathrm{N}_{2}$. However, for the three complexes the fill factor (FF) remains low with average values in the range $27-32 \%$. Surprisingly, thermal annealing of the $\mathrm{CpCoCb}(3 \mathrm{~T})_{4}$ devices (see experimental details in the ESI $\dagger$ ) leads to a reduced $J_{\text {sc }}=2.2 \mathrm{~mA} \mathrm{~cm}^{-2}$. The low PCEs measured in open air indicate that the complexes photooxidize as previously reported for some thiophene derivatives. $^{21}$

The EQE spectrum of OSCs based on $\mathrm{CpCoCb}(3 \mathrm{~T})_{4}$ (Fig. 2b) spans all over the visible range with two maxima at $390 \mathrm{~nm}$ and $430 \mathrm{~nm}$, as well as two shoulders at $490 \mathrm{~nm}$ and $600 \mathrm{~nm}$. The peaks at $390 \mathrm{~nm}$ and $430 \mathrm{~nm}$ probably arise from the absorption of the four conjugated $3 \mathrm{~T}$ arms. On the other hand the weak intensity shoulder at $600 \mathrm{~nm}$ is consistent with a metalligand charge transfer (MLCT) transition between the Co atom and the azimuthal organic ligands. Fig. $2 \mathrm{~b}$ reveals that optical absorption in the 480-700 nm range contributes more efficiently to PV conversion as compared to the 350-480 $\mathrm{nm}$ range. This could arise from a longer lifetime of excitons generated by an MLCT transition due to the strong spin-orbit coupling of the Co atom that stabilizes triplet states.

In summary, three $\operatorname{CpCoCb}(n \mathrm{~T})_{4}$ complexes bearing four oligothiophene arms of different lengths have been synthetized and investigated as donor materials in solution-processed $\mathrm{BHJ}$ solar cells. In particular, devices elaborated with $\mathrm{CpCoCb}(3 \mathrm{~T})_{4}$ show $V_{\text {oc }}$ values beyond $0.7 \mathrm{~V}$ and reach PCEs of $1.9 \%$ and $2.1 \%$ under an incident power of 75 and $22 \mathrm{~mW} \mathrm{~cm}^{-2}$ respectively. Tailoring the four oligothiophene arms (length, substituents, etc.) of the $\operatorname{CpCoCb}(n \mathrm{~T})_{4}$ building block should allow us to considerably improve these promising PV performances.

\section{Notes and references}

1 For a recent review on BHJs see: (a) A. J. Heeger, Adv. Mater., 2014, 26, 10; (b) M. C. Scharber, D. Mühlbacher, M. Koppe, P. Denk, C. Waldauf, A. J. Heeger and C. J. Brabec, Adv. Mater., 2006, 18, 789; (c) S. H. Park, A. Roy, S. Beaupré, S. Cho, N. Coates, J. S. Moon, D. Moses, M. Leclerc, K. Lee and A. J. Heeger, Nat. Photonics, 2009, 3, 297; (d) C. J. Brabec, S. Gowrisanker, J. J. M. Halls, D. Laird, S. Jia and S. P. Williams, Adv. Mater., 2010, 22, 3839; (e) P.-L. T. Boudreault, A. Najari and M. Leclerc, Chem. Mater., 2011, 23, 456; $(f)$ D. Gendron and M. Leclerc, Energy Environ. Sci., 2011, 4, 1225; $(g)$ G. Li, R. Zhu and Y. Yang, Nat. Photonics, 2012, 6, 153; $(h)$ J. B. You, L. T. Dou, K. Yoshimura, T. Kato, K. Ohya, T. Moriarty, K. Emery, C.-C. Chen, J. Gao, G. Li and Y. Yang, Nat. Commun., 2013, 4, 1446; (i) G. Dennler, S. Bereznev, D. Fichou, K. Holl, D. Ilic, R. Koeppe, M. Krebs, A. Labouret, C. Lungenschmied, A. Marchenko, D. Meissner, E. Mellikov, J. Meot, A. Meyer, T. Meyer, H. Neugebauer, A. Opik, N. S. Sariciftci, S. Taillemite and T. Wohrle, Sol. Energy, 2007, 81, 947.

2 (a) J. Roncali, Acc. Chem. Res., 2009, 42, 1719; (b) Y. Sun, G. C. Welch, W. L. Leong, C. J. Takacs, G. C. Bazan and A. J. Heeger, Nat. Mater., 2012, 11, 44; (c) B. Walker, C. Kim and T.-Q. Nguyen, Chem. Mater., 2011, 23, 470; (d) A. Mishra and P. Bauerle, Angew. Chem., Int. Ed., 2012, 51, 2020; (e) J. E. Coughlin, Z. B. Henson, G. C. Welch and G. C. Bazan, Acc. Chem. Res., 2014, 47, 257; $(f)$ D. Demeter, T. Rousseau, P. Leriche, T. Cauchy, R. Po and J. Roncali, Adv. Funct. Mater., 2011, 21, 4379; $(g)$ N. F. Montcada, B. Pelado, A. Viterisi, J. Albero, J. Coro, P. de la Cruz, F. Langa and E. Palomares, Org. Electron., 2013, 14, 2826; (h) L. W. Leong, G. C. Welch, L. G. Kaake, C. J. Takacs, Y. Sun, G. C. Bazan and A. J. Heeger, Chem. Sci., 2012, 3, 2103; (i) C. J. Takacs, Y. Sun, G. C. Welch, L. A. Perez, X. Liu, W. Wen, G. C. Bazan and A. J. Heeger, J. Am. Chem. Soc., 2012, 134, 16597.

3 (a) F. Silvestri, M. D. Irwin, L. Beverina, A. Facchetti, G. a Pagani and T. J. Marks, J. Am. Chem. Soc., 2008, 130, 17640; (b) X. Xiao, G. Wei, S. Wang, J. D. Zimmerman, C. K. Renshaw, M. E. Thompson and 
S. R. Forrest, Adv. Mater., 2012, 24, 1956; (c) B. E. Lassiter, J. D. Zimmerman and S. R. Forrest, Appl. Phys. Lett., 2013, 103, 123305.

4 M. G. Walter, A. B. Rudine and C. C. Wamser, J. Porphyrins Phthalocyanines, 2010, 14, 759.

5 (a) S. Qu and H. Tian, Chem. Commun., 2012, 48, 3039; (b) S.-Y. Liu, W.-F. Fu, J.-Q. Xu, C.-C. Fan, H. Jiang, M. Shi, H.-Y. Li, J.-W. Chen, Y. Cao and H.-Z. Chen, Nanotechnology, 2014, 25, 014006.

6 J. Zhou, Y. Zuo, X. Wan, G. Long, Q. Zhang, W. Ni, Y. Liu, Z. Li, G. He, C. Li, B. Kan, M. Li and Y. Chen, J. Am. Chem. Soc., 2013, 135,8484 .

7 (a) S. Steinberger, A. Mishra, E. Reinold, J. Levichkov, C. Uhrich, M. Pfeiffer and P. Bauerle, Chem. Commun., 2011, 47, 1982; (b) J. H. Choi, M. E. El-Khouly, T. Kim, Y.-S. Kim, U. C. Yoon, S. Fukuzumi and K. Kim, Int. J. Photoenergy, 2013, 843615.

8 (a) G. Horowitz, F. Kouki, P. Spearman, D. Fichou, C. Nogues, X. Pan and F. Garnier, Adv. Mater., 1996, 8, 242; (b) J. C. Johnson, A. J. Nozik and J. Michl, Acc. Chem. Res., 2013, 46, 1290; (c) J. C. Johnson, A. Akdag, M. Zamadar, X. Chen, A. F. Schwerin, I. Paci, M. B. Smith, Z. Havlas, J. R. Miller, M. A. Ratner, A. J. Nozik and J. Michl, J. Phys. Chem. B, 2013, 117, 4680; (d) Y.-Q. Zheng, Y.-Z. Dai, Y. Zhou, J.-Y. Wang and J. Pei, Chem. Commun., 2014, 50, 1591.

9 A. K. K. Kyaw, D. H. Wang, V. Gupta, J. Zhang, S. Chand, G. C. Bazan and A. J. Heeger, Adv. Mater., 2013, 25, 2397.

10 (a) M. Graetzel, Inorg. Chem., 2005, 44, 6841; (b) K. Nazeeruddin and M. Graetzel, Photofunctional Transition Metal Complexes, 2007, vol. 123, pp. 113-175; (c) H. Choi, C. Nahm, J. Kim, C. Kim, S. Kang, T. Hwang and B. Park, Current Appl. Phys., 2013, 13, S2; (d) S. De Souza, L. Oliveira and M. De Andrade, Nanoenergy, Springer Berlin Heidelberg, Berlin, Heidelberg, 2013; (e) T. A. Clem, D. F. J. Kavulak, E. J. Westling and J. M. J. Frechet, Chem. Mater., 2010, 22, 1977; $(f)$ W. Lee, T.-H. Kwon, J. Kwon, J.-Y. Kim, C. Lee and J.-I. Hong, New J. Chem., 2011, 35, 2557; (g) W.-Y. Wong and C.-L. Ho, Acc. Chem. Res., 2010, 43, 1246.
11 (a) C. W. Tang, Appl. Phys. Lett., 1986, 48, 183; (b) Y. Matsuo, Y. Sato, T. Niinomi, I. Soga, H. Tanaka and E. Nakamura, J. Am. Chem. Soc., 2009, 131, 16048; (c) V. K. Singh, R. K. Kanaparthi and L. Giribabu, RSC Adv., 2014, 4, 6970.

12 (a) D. Fichou, J. Pouliquen, J. Kossanyi, M. Jakani, G. Campet and J. Claverie, J. Electroanal. Chem., 1985, 188, 167; (b) V. N. Kuznetsov and N. Serpone, J. Phys. Chem. C, 2009, 113, 15110; (c) M. Jakani, G. Campet, J. Claverie, D. Fichou, J. Pouliquen and J. Kossanyi, J. Solid State Chem., 1985, 56, 269; (d) H. Yu, S. C. Yan, Z. S. Li, T. Yu and Z. G. Zou, Int. J. Hydrogen Energy, 2012, 37, 12120; $(e)$ D. Fichou and J. Kossanyi, J. Electrochem. Soc., 1986, 133, 1607; $(f)$ H. Yu, J. Wang, S. Yan, T. Yu and Z. G. Zou, J. Photochem. Photobiol., A, 2014, 275, 65.

13 D. Fichou, J. Mater. Chem., 2000, 10, 571.

14 (a) X. Zheng, M. E. Mulcahy, D. Horinek, F. Galeotti, T. F. Magnera and J. Michl, J. Am. Chem. Soc., 2004, 126, 4540; (b) M. E. Mulcahy, T. F. Magnera and J. Michl, J. Phys. Chem. C, 2009, 113, 20698.

15 D. C. Caskey, T. Yamamoto, C. Addicott, R. K. Shoemaker, J. Vacek, A. M. Hawkridge, D. C. Muddiman, G. S. Kottas, J. Michl and P. J. Stang, J. Am. Chem. Soc., 2008, 130, 7620.

16 H. V. Nguyen, D. C. D. Butler and C. J. Richards, Org. Lett., 2006, 8, 769.

17 E. M. Harcourt, S. R. Yonis, D. E. Lynch and D. G. Hamilton, Organometallics, 2008, 3819, 1653.

18 A. Geny, N. Agenet, L. Iannazzo, M. Malacria, C. Aubert and V. Gandon, Angew. Chem., Int. Ed., 2009, 48, 1810.

19 G. Bertrand, L. Tortech, D. Fichou, M. Malacria, C. Aubert and V. Gandon, Organometallics, 2012, 31, 126.

20 B. W. D'Andrade, S. Datta, S. R. Forrest, P. Djurovich, E. Polikarpov and M. E. Thompson, Org. Electron., 2005, 6, 11.

21 (a) H. Hintz, H.-J. Egelhaaf, H. Peisert and T. Chassé, Polym. Degrad. Stab., 2010, 95, 818; (b) Y. Aoyama, T. Yamanari, N. Koumura, H. Tachikawa, M. Nagai and Y. Yoshida, Polym. Degrad. Stab., 2013, 98, 899. 